\title{
The influence of self-doping of stibnite ore with impurities on the preparation, heat capacity, magnetic and transport properties of tetrahedrite $\mathrm{Cu}_{12} \mathrm{Sb}_{4} \mathrm{~S}_{13}$
}

\author{
YUQI CHEN ${ }^{1,3}$, LIANG LI $^{2,3, *}$, QIANJUN ZHANG ${ }^{1}$, CONGZHENG ZHANG $^{2}$, SHINJI HIRAI $^{3}$ \\ ${ }^{1}$ School of Mechanical Engineering, Shanghai Dian Ji University, Shanghai, 201306, China \\ ${ }^{2}$ School of Mechatronics Engineering, Nanyang Normal University, Henan, 473061, China \\ ${ }^{3}$ Department of Material Science and Engineering, Muroran Institute of Technology, Muroran 050-8585, Japan
}

\begin{abstract}
Stibnite mineral (mainly $\mathrm{Sb}_{2} \mathrm{~S}_{3}$ ) has been employed for the synthesis of tetrahedrite $\mathrm{Cu}_{12} \mathrm{Sb}_{4} \mathrm{~S}_{13}$ bulk material by spark plasma sintering. High purity $\mathrm{Cu}_{12} \mathrm{Sb}_{4} \mathrm{~S}_{13}$ can be quickly obtained by two sintering procedures at temperatures from the range of $420{ }^{\circ} \mathrm{C}$ to $440{ }^{\circ} \mathrm{C}$ for $1 \mathrm{~h}$. Appropriate reduction of $\mathrm{Cu}$ content $\left(\mathrm{Cu}_{12+\mathrm{x}} \mathrm{Sb}_{4} \mathrm{~S}_{13}, \mathrm{x} \leqslant-0.05\right)$ or $\mathrm{CuS}$ content $\left(\mathrm{Cu}_{12-\mathrm{y}} \mathrm{Sb}_{4} \mathrm{~S}_{13-\mathrm{y}}\right.$, $\mathrm{y}=0.1$ or 0.3 ) was beneficial to fabricate $\mathrm{Cu}_{12} \mathrm{Sb}_{4} \mathrm{~S}_{13}$. The secondary resintering improved the purity of $\mathrm{Cu}_{12} \mathrm{Sb}_{4} \mathrm{~S}_{13} \mathrm{material}$. The first-order magnetic phase transformation with magnetic hysteresis effect was confirmed by the behavior of susceptibility, heat capacity and resistivity. The magnetization showed a linear increase with increasing field (up to $7 \mathrm{~T}$ ) and non-saturation behavior was observed. The impurities in stibnite mineral $\mathrm{Sb}_{2} \mathrm{~S}_{3}$ had a weak influence on the transformation temperature but affected the low-temperature magnetization value $(\sim 0.15$, close to natural tetrahedrite). Similar transformation was observed by the analysis of heat capacity. The properties such as electrical resistivity, Seebeck coefficient and thermal conductivity were also measured for $\mathrm{Cu}_{11.9} \mathrm{Sb}_{4} \mathrm{~S}_{13}$ and $\mathrm{Cu}_{11.9} \mathrm{Sb}_{4} \mathrm{~S}_{12.9}$. The maximum figure of merit $\mathrm{ZT}$ of $\mathrm{Cu}_{11.9} \mathrm{Sb}_{4} \mathrm{~S}_{12.9}$ was 0.22 at $367 \mathrm{~K}$.
\end{abstract}

Keywords: tetrahedrite; $\mathrm{Cu}_{12} \mathrm{Sb}_{4} \mathrm{~S}_{13}$; phase transition; magnetization; heat capacity.

\section{Introduction}

Thermoelectric materials can convert waste heat into electrical energy, thus they are expected to play an important role in future energy generation and conversion $[1,2]$. Tetrahedrite $\mathrm{Cu}_{12+\mathrm{m}} \mathrm{Sb}_{4+\mathrm{n}} \mathrm{S}_{13}(0 \leqslant \mathrm{~m} \leqslant 1.92,-0.02 \leqslant \mathrm{n} \leqslant$ 0.27 ) with a wide composition range paved the way to many new and low-cost thermoelectric energy generation opportunities [3, 4]. This mineral exhibits a metal-semiconductor transition (MST) at $85 \mathrm{~K}$ [5] and good thermoelectric properties at high temperatures [6].

Traditionally, $\mathrm{Cu}_{12} \mathrm{Sb}_{4} \mathrm{~S}_{13}$ has been synthesized by melting reaction of the elements [3, 6-11] or compounds such as $\mathrm{CuS}, \mathrm{Cu}_{2} \mathrm{~S}_{\text {and }} \mathrm{Sb}_{2} \mathrm{~S}_{4}$ [12] and $\mathrm{CuS}, \mathrm{Sb}_{2} \mathrm{~S}_{3}$ and $\mathrm{Cu}[13]$ and heat treatment, which is time-consuming (about 3 days for melting and 2 weeks for annealing [3]). Spark plasma sintering

*E-mail: liliangjdgc@nynu.edu.cn
(SPS) technology was employed for the preparation of $\mathrm{Cu}_{12} \mathrm{Sb}_{4} \mathrm{~S}_{13}$ to shorten the time and reduce energy-consumption [14]. $\mathrm{Cu}_{12} \mathrm{Sb}_{4} \mathrm{~S}_{13}$ can be obtained from its elemental powder by powder metallurgical process combining mechanical alloying (MA) and SPS at $723 \mathrm{~K}$ for $10 \mathrm{~min}$. It is important to be able to prepare $\mathrm{Cu}_{12} \mathrm{Sb}_{4} \mathrm{~S}_{13}$ without mechanical alloying from other raw materials in the fast and scalable process.

Natural tetrahedrite minerals are potential starting materials for the preparation of $\mathrm{Cu}_{12} \mathrm{Sb}_{4} \mathrm{~S}_{13}$. However, the maximum ZT value of $\mathrm{Cu}_{12} \mathrm{Sb}_{4} \mathrm{~S}_{13}$ synthesized from four sulfosalt minerals of tetrahedrite-tennantite series was low (ZT value about 0.13 at $700 \mathrm{~K}$ ) [15] due to tetrahedritetennantite electrical resistivity, which was far less than that of $\mathrm{Cu}_{12} \mathrm{Sb}_{4} \mathrm{~S}_{13}$ (ZT value about 1 at $700 \mathrm{~K}[4-6,16])$. Single phase $\mathrm{Cu}_{12} \mathrm{Sb}_{4} \mathrm{~S}_{13}$ was obtained from natural minerals such as the "seed matrix" $[4,16]$ which demonstrated a novel route for the preparation of $\mathrm{Cu}_{12} \mathrm{Sb}_{4} \mathrm{~S}_{13}[4,16]$. On the other 
hand, transition metal elements (Mn [7, 10, 17, 18], Fe [19, 20], Co [21], Ni [8, 22], Sn [23], Pb [24] Bi [25] and $\mathrm{Zn}$ [26]) used for doping $\mathrm{Cu}_{12} \mathrm{Sb}_{4} \mathrm{~S}_{13}$ have been extensively studied to enhance the thermoelectric properties of the material. Moreover, higher amounts of Fe-doped tetrahedrite $[19,20]$ and tetrahedrites co-doped with $\mathrm{Ni}$ and $\mathrm{Zn}$ [27] demonstrated improved ZT values. Stibnite ore consists of $\mathrm{Sb}_{2} \mathrm{~S}_{3}$ and impurities (Fe and As, etc.). It is important to utilize stibnite for the synthesis of $\mathrm{Cu}_{12} \mathrm{Sb}_{4} \mathrm{~S}_{13}$ and study the influence of self-doping of stibnite ore with impurities on the preparation, heat capacity, magnetic and transport properties of tetrahedrite $\mathrm{Cu}_{12} \mathrm{Sb}_{4} \mathrm{~S}_{13}$. Besides, no report has employed stibnite ore $\mathrm{Sb}_{2} \mathrm{~S}_{3}$ to prepare $\mathrm{Cu}_{12} \mathrm{Sb}_{4} \mathrm{~S}_{13}$ by SPS.

In this work, $\mathrm{Cu}_{12} \mathrm{Sb}_{4} \mathrm{~S}_{13}$ compacts were directly sintered from stibnite ore $\mathrm{Sb}_{2} \mathrm{~S}_{3}, \mathrm{Cu}$ and $\mathrm{CuS}$ by SPS without ball milling treatment. The influence of two-stage sintering process, sintering temperature, resintering, and the ratio of $\mathrm{Cu}$ and $\mathrm{CuS}$ mixture on the preparation of $\mathrm{Cu}_{12} \mathrm{Sb}_{4} \mathrm{~S}_{13}$ was systematically investigated. The structural, specific heat, magnetic and transport properties of the synthesized $\mathrm{Cu}_{12} \mathrm{Sb}_{4} \mathrm{~S}_{13}$ were studied and compared with the reported properties of $\mathrm{Cu}_{12} \mathrm{Sb}_{4} \mathrm{~S}_{13}$ to investigate the influence of impurities from stibnite ore $\mathrm{Sb}_{2} \mathrm{~S}_{3}$.

\section{Experimental}

Table 1 lists the comparison of chemical compositions of stibnite mineral powders and commercial $\mathrm{Sb}_{2} \mathrm{~S}_{3}$ powders (purity $99.99 \%$, Kojundo Chemical Laboratory Co., Ltd.). Chemical analysis (unit: wt. \% of stibnite $\mathrm{Sb}_{2} \mathrm{~S}_{3}$ ) was performed by using the ICP-MS method. Stibnite $\mathrm{Sb}_{2} \mathrm{~S}_{3}$ contains higher $\mathrm{Fe}$ and As content because it is made direct from octahedral copper ore. $\mathrm{CuS}$ powders (purity $99 \%$, average size $150 \mu \mathrm{m}$ ) and $\mathrm{Cu}$ powders (purity $99.99 \%$, average size $1 \mu \mathrm{m}$ ) from Kojundo Chemical Laboratory Co., Ltd., were employed.

$\mathrm{Cu}_{12+\mathrm{x}} \mathrm{Sb}_{4} \mathrm{~S}_{13} \quad(-0.15 \leqslant \mathrm{x} \leqslant 0.05)$ and $\mathrm{Cu}_{12-\mathrm{y}} \mathrm{Sb}_{4} \mathrm{~S}_{13-\mathrm{y}}(0 \leqslant \mathrm{y} \leqslant 0.5)$ were weighed in a mole ratio of $\mathrm{Sb}_{2} \mathrm{~S}_{3}: \mathrm{Cu}: \mathrm{CuS}=2: 5+$ $\mathrm{x}$ : $7-\mathrm{y}$. The mixed powders were placed in a graphite mold (diameter of $10.5 \mathrm{~mm}$ ) and sintered by SPS. Two-stage procedure was tested to check the decomposition of $\mathrm{CuS}$ at above $220^{\circ} \mathrm{C}$ by holding the $\mathrm{CuS}$ at $220^{\circ} \mathrm{C}$ for $0.5 \mathrm{~h}$. To ensure stability of $\mathrm{Cu}_{12} \mathrm{Sb}_{4} \mathrm{~S}_{13}[12,28]$, the sintering temperature was limited to the range of $400{ }^{\circ} \mathrm{C}$ to $460{ }^{\circ} \mathrm{C}$ to produce $\mathrm{Cu}_{12} \mathrm{Sb}_{4} \mathrm{~S}_{13}$. The heating rate was $10{ }^{\circ} \mathrm{C} / \mathrm{min}$. The primary sintered $\mathrm{Cu}_{12} \mathrm{Sb}_{4} \mathrm{~S}_{13}$ compacts were broken and milled. The resintering procedure is a one-step procedure. The physical properties of resintered samples were studied.

X-ray diffraction (XRD, Model Rint-Ultima+, Rigaku Corp., Tokyo, Japan) with monochromatic $\mathrm{CuK} \alpha$ radiation at $40 \mathrm{kV}$ and $20 \mathrm{~mA}$ was applied. Lattice parameters of the synthetics were measured with the scan step of $1.0 \times 10^{-3}$ degree for $2 \mathrm{~s}$. Normalized relative intensities were determined using the intensity ratio of the fixed diffraction lines of each reaction product.

$$
I_{\mathrm{Cu}_{3} S b S_{4}(111)}=\frac{I_{\mathrm{Cu}_{3} S b S_{4}(111)}}{I_{\mathrm{Cu}_{3} S b S_{4}(111)}+I_{C u_{12} S b_{4} S_{13}(222)}}
$$

$\mathrm{CuS}$ and $\mathrm{Cu}_{3} \mathrm{SbS}_{4}$ were distinguished based on the planes $\left(\begin{array}{lll}0 & 0 & 2\end{array}\right)$ and $\left(\begin{array}{lll}1 & 0 & 1\end{array}\right)$ of $\mathrm{Cu}_{3} \mathrm{SbS}_{4}$. Morphology of synthetic $\mathrm{Cu}_{12} \mathrm{Sb}_{4} \mathrm{~S}_{13}$ was characterized by scanning electron microscopy (SEM, JSM-5310LV, JEOL, Ltd., Tokyo, Japan). The specific heat measurements were carried out by the thermal relaxation method with a physical properties measurement system (PPMS; Quantum Design Inc.). The DC magnetic susceptibility was measured with a magnetic properties measurement system (MPMS, Quantum Design Inc.). Thermal conductivity, resistivity and Seebeck coefficient were measured by a Quantum Design PPMS in $2 \mathrm{~K}$ to $400 \mathrm{~K}$ range under vacuum. Total thermal conductivity and Seebeck coefficient were evaluated by two-terminal DC method. Electrical resistivity measurement was performed on the same samples by standard four-probe method.

\section{Results and discussion}

\subsection{Influence of sintering procedure and temperature on synthesis of $\mathrm{Cu}_{12} \mathrm{Sb}_{4} \mathrm{~S}_{13}$}

Two kinds of sintering procedures were employed to synthesize the $\mathrm{Cu}_{12} \mathrm{Sb}_{4} \mathrm{~S}_{13}$ compacts at 
Table 1. Chemical composition of stibnite mineral and commercial $\mathrm{Sb}_{2} \mathrm{~S}_{3}$ powders.

\begin{tabular}{ccccccccccccc}
\hline Element & $\mathrm{Sb}$ & $\mathrm{As}$ & $\mathrm{Pb}$ & $\mathrm{Fe}$ & $\mathrm{Si}$ & $\mathrm{Sn}$ & $\mathrm{Cu}$ & $\mathrm{Bi}$ & $\mathrm{Zn}$ & $\mathrm{Ni}$ & $\mathrm{S}$ \\
\hline \hline $\mathrm{Sb}_{2} \mathrm{~S}_{3}$ & Stibnite & 74.7 & 0.023 & 0.005 & 0.132 & 0.003 & 0.001 & 0.001 & 0.001 & 0.001 & 0.001 & 28 \\
composition [wt.\%] high purity & 74.5 & 0.001 & 0.002 & 0.002 & 0.002 & $<0.001$ & $<0.001$ & 0.001 & $<0.001$ & $<0.001$ & 27 \\
\hline
\end{tabular}

the temperatures of $400{ }^{\circ} \mathrm{C}$ to $440{ }^{\circ} \mathrm{C}$ for $1 \mathrm{~h}$. The main product $\mathrm{Cu}_{12} \mathrm{Sb}_{4} \mathrm{~S}_{13}$ is shown in Fig. 1. The two-step procedure gave similar result to one-step procedure though $\mathrm{CuS}$ decomposed at near $220^{\circ} \mathrm{C}$. Moreover, the peak position of $\mathrm{Cu}_{12} \mathrm{Sb}_{4} \mathrm{~S}_{13}$ shifted to lower angle as sintering temperature increased, indicating that the lattice constant increased with an increase of temperature. It should be pointed out that the synthesis temperature could be reduced to $400{ }^{\circ} \mathrm{C}$, which is lower than reported in the literature [19] $\left(450{ }^{\circ} \mathrm{C}\right)$.

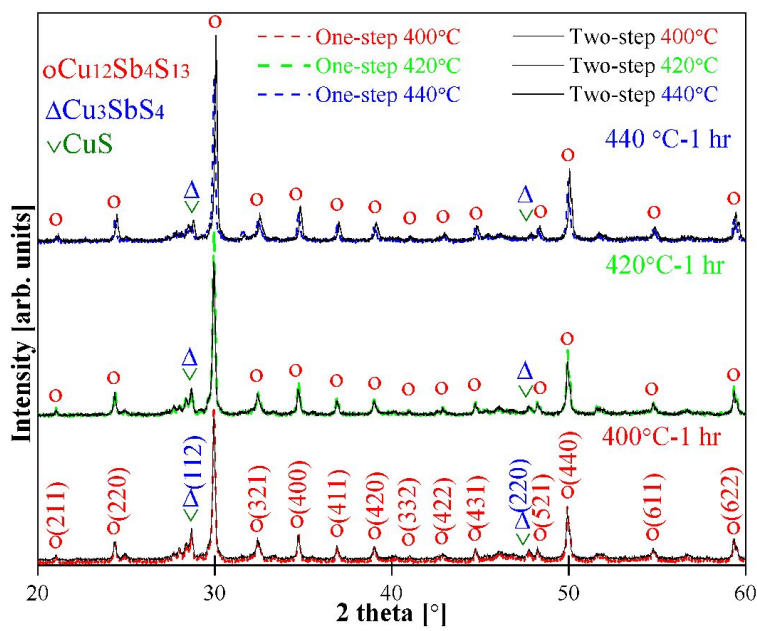

Fig. 1. XRD patterns of $\mathrm{Cu}_{12} \mathrm{Sb}_{4} \mathrm{~S}_{13}$ sintered at $400{ }^{\circ} \mathrm{C}$ to $440{ }^{\circ} \mathrm{C}$ in one-step and two-step procedure.

\subsection{Variation of $\mathrm{Cu} / \mathrm{CuS}$ content and re- sintering on the preparation of $\mathrm{Cu}_{12} \mathrm{Sb}_{4} \mathrm{~S}_{13}$}

The influence of $\mathrm{S}$ content in raw material and resintering on the impurity phase $\mathrm{Cu}_{3} \mathrm{SbS}_{4}$ has been researched [14]. In this study, we varied the $\mathrm{Cu} / \mathrm{CuS}$ content. Fig. 2a shows XRD patterns of primary-sintered and resintered $\mathrm{Cu}_{12+\mathrm{x}} \mathrm{Sb}_{4} \mathrm{~S}_{13}(\mathrm{x}=$ $-0.15-0.05)$ compacts. High purity $\mathrm{Cu}_{12} \mathrm{Sb}_{4} \mathrm{~S}_{13}$ can be synthesized by changing the $\mathrm{Cu}$ content. The peak position of $\mathrm{Cu}_{12} \mathrm{Sb}_{4} \mathrm{~S}_{13}$ shifts to lower angle as $\mathrm{Cu}$ content reduces, indicating that the lattice constant of $\mathrm{Cu}_{12} \mathrm{Sb}_{4} \mathrm{~S}_{13}$ has been reduced. XRD patterns of primary sintered and resintered compacts prepared with various $\mathrm{CuS}$ contents are shown in Fig. 2b. Similar to secondary sintering results, high purity $\mathrm{Cu}_{12} \mathrm{Sb}_{4} \mathrm{~S}_{13}$ can be prepared by secondary sintering following the change in $\mathrm{CuS}$ content.
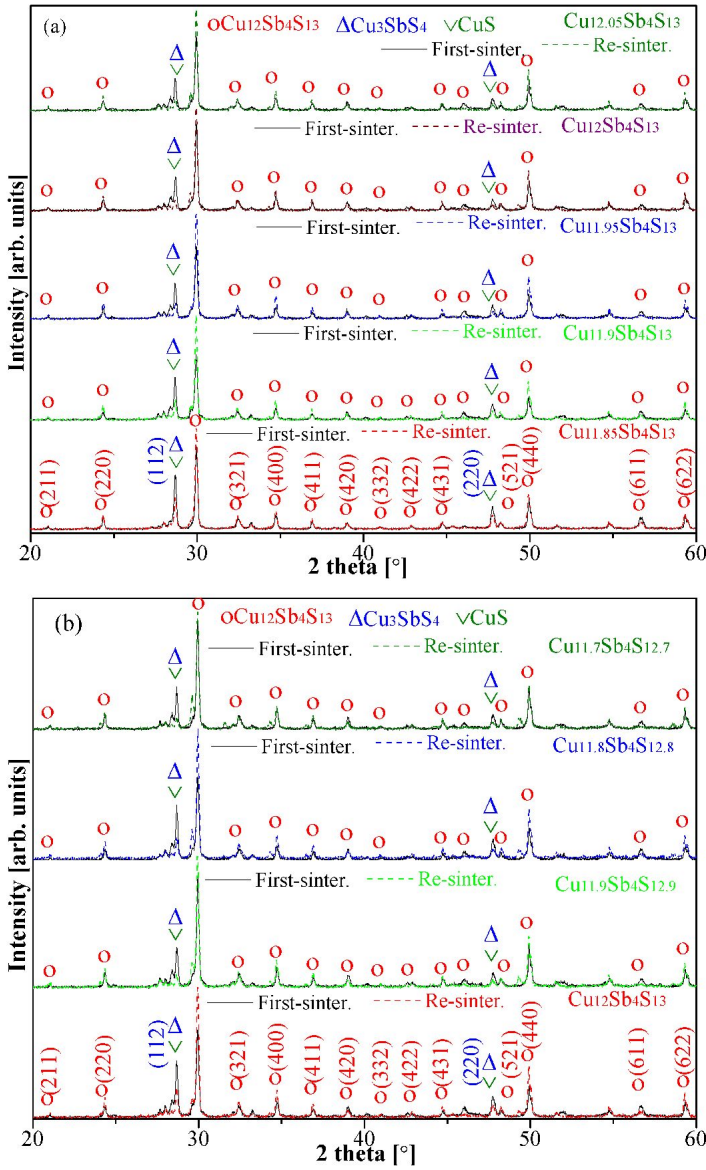

Fig. 2. XRD patterns of primary sintered and resintered $\mathrm{Cu}_{12} \mathrm{Sb}_{4} \mathrm{~S}_{13}$ compacts with various $\mathrm{Cu}$ (a) and $\mathrm{CuS}$ (b) contents.

Fig. 3a shows relative intensity of primary and resintered $\mathrm{Cu}_{12+\mathrm{x}} \mathrm{Sb}_{4} \mathrm{~S}_{13}(\mathrm{x}=-0.15-0.05)$ 
compacts. The intensity of characteristic peaks of $\mathrm{Cu}_{3} \mathrm{SbS}_{4}$ has reduced as $\mathrm{Cu}$ content decreased and attained the minimum for $\mathrm{x}=-0.1$. Moreover, resintering can obviously reduce the content of $\mathrm{Cu}_{3} \mathrm{SbS}_{4}$. When $\mathrm{Cu}$ content $(\mathrm{x}=0.05)$ was larger than stoichiometric, the characteristic peak of $\mathrm{Cu}_{3} \mathrm{SbS}_{4}$ enhanced. Combined with the phase diagram [29], the reduction of $\mathrm{Cu}$ content was advantageous for the synthesis of $\mathrm{Cu}_{12} \mathrm{Sb}_{4} \mathrm{~S}_{13}$. Compared with the stoichiometric result, excess of $\mathrm{Cu}$ was disadvantageous for the synthesis of $\mathrm{Cu}_{12} \mathrm{Sb}_{4} \mathrm{~S}_{13}$, which is consistent with the analysis of $\mathrm{Cu}-\mathrm{Sb}-\mathrm{S}$ ternary phase diagram reported by Welch et al. [29].

During primary sintering, the intensity of characteristic peaks for $\mathrm{Cu}_{3} \mathrm{SbS}_{4}$ obviously reduced for $\mathrm{Cu}_{12-\mathrm{x}} \mathrm{Sb}_{4} \mathrm{~S}_{13-\mathrm{x}}(\mathrm{x}=0.1$ and 0.3$)$ nominal compositions with the reduction of $\mathrm{CuS}$ content as shown in Fig. 3b. The simultaneous reduction of both $\mathrm{Cu}$ and $\mathrm{S}$ content can promote high purity $\mathrm{Cu}_{12} \mathrm{Sb}_{4} \mathrm{~S}_{13}$. Moreover, the existence of Fe impurity $(0.13 \%)$ in stibnite mineral had little effect on the preparation of $\mathrm{Cu}_{12} \mathrm{Sb}_{4} \mathrm{~S}_{13}$, which was similar to Fe substitution $\mathrm{Cu}_{12} \mathrm{Sb}_{4} \mathrm{~S}_{13}[6,18-20]$.
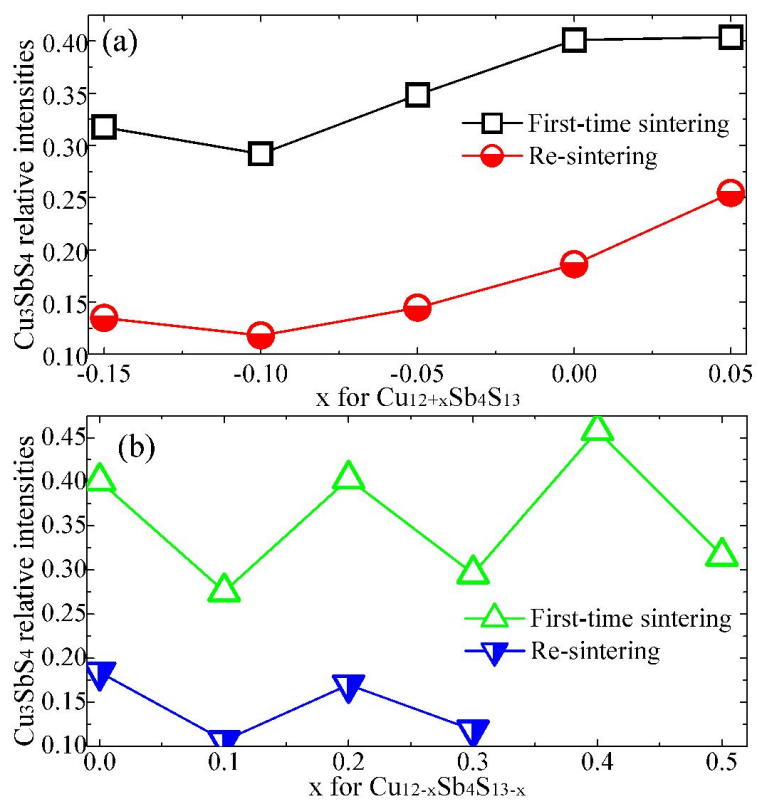

Fig. 3. Dependencies of $\mathrm{Cu}_{3} \mathrm{SbS}_{4}$ relative intensities on variation of $\mathrm{Cu}$ (a) and $\mathrm{CuS}(\mathrm{b})$.

Fig. 4 shows SEM images of typical resintered compacts. In Fig. $4 \mathrm{a}, \mathrm{Cu}_{12} \mathrm{Sb}_{4} \mathrm{~S}_{13}$ has some
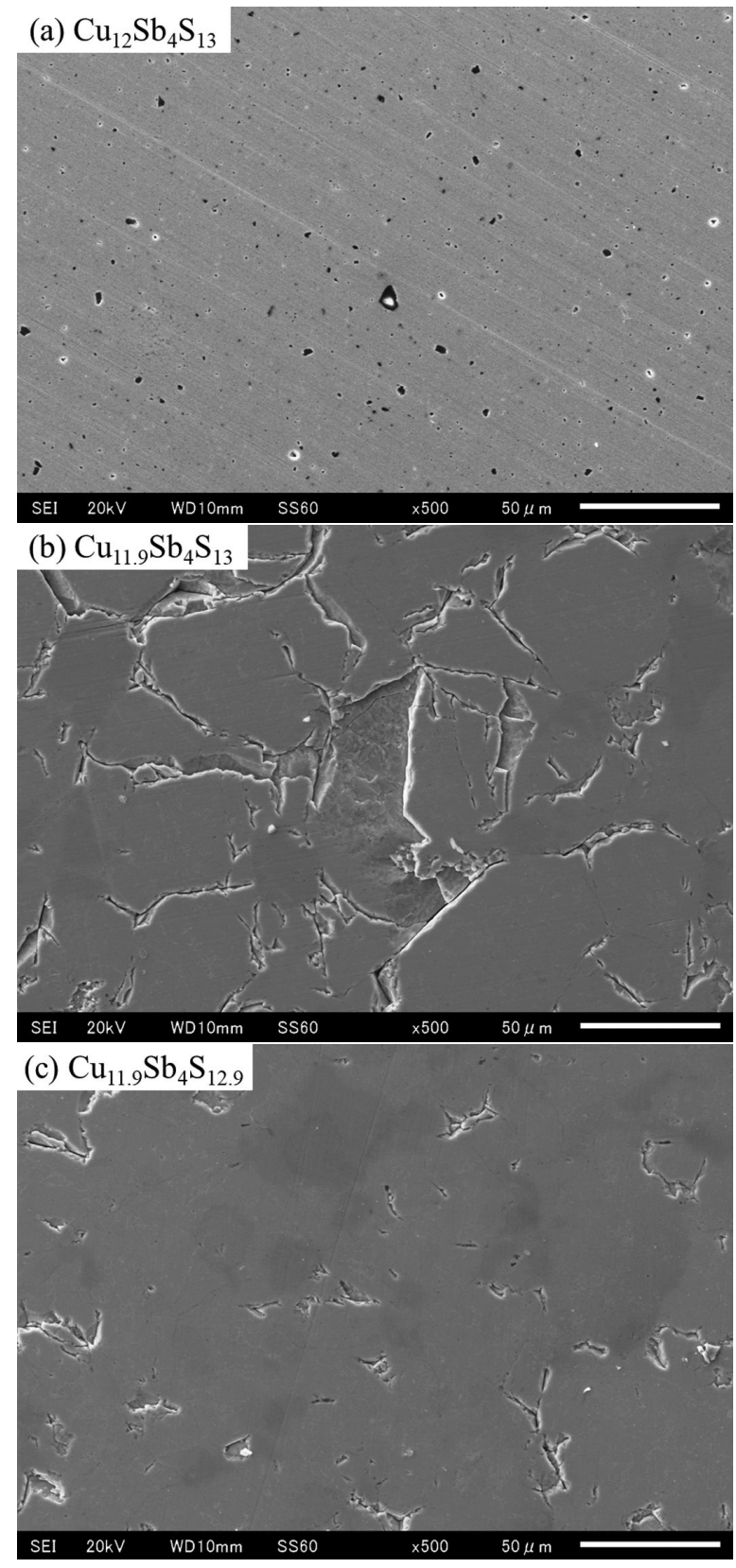

Fig. 4. SEM images of resintered $\mathrm{Cu}_{12} \mathrm{Sb}_{4} \mathrm{~S}_{13}$ (a), $\mathrm{Cu}_{11.9} \mathrm{Sb}_{4} \mathrm{~S}_{13}$ (b), and $\mathrm{Cu}_{11.9} \mathrm{Sb}_{4} \mathrm{~S}_{12.9}$ (c).

residual pores. The holes on the surface of $\mathrm{Cu}_{12} \mathrm{Sb}_{4} \mathrm{~S}_{13}$ compacts are possibly due to the sulfur loss and vacuum sintering. In Fig. 4 b, $\mathrm{Cu}_{11.9} \mathrm{Sb}_{4} \mathrm{~S}_{13}$ has a large amount of crystal boundaries and defects, which is similar to that reported in [14]. In Fig. $4 c, \mathrm{Cu}_{11.9} \mathrm{Sb}_{4} \mathrm{~S}_{12.9}$ has less holes than $\mathrm{Cu}_{11.9} \mathrm{Sb}_{4} \mathrm{~S}_{13}$. 


\subsection{Magnetization and heat capacity of synthetic $\mathrm{Cu}_{12} \mathrm{Sb}_{4} \mathbf{S}_{13}$}

Temperature dependencies of magnetic susceptibility $\chi$ for $\mathrm{Cu}_{12} \mathrm{Sb}_{4} \mathrm{~S}_{13}, \mathrm{Cu}_{11.9} \mathrm{Sb}_{4} \mathrm{~S}_{13}$, and $\mathrm{Cu}_{11.9} \mathrm{Sb}_{4} \mathrm{~S}_{12.9}$ in the temperature range of $2 \mathrm{~K}$ to $300 \mathrm{~K}$ at $1 \mathrm{~T}$ are shown in Fig. 5. All $\chi(\mathrm{T})$ graphs show anomalous drop at $90 \mathrm{~K}$. The drastic change can also be observed in heat capacity, resistivity and Seebeck coefficient (which will be shown later). This anomalous drop is associated with a magnetic phase transition. For all samples, $\chi(T)$ exhibits the Pauli-paramagnetic behavior except the sharp drop at around $90 \mathrm{~K}$, below which $\chi(\mathrm{T})$ remains positive. $\chi(\mathrm{T})$ is similar to that of polycrystalline $\mathrm{Cu}_{12} \mathrm{Sb}_{4} \mathrm{~S}_{13}$ synthesized through the heating of a mixture of $\mathrm{CuS}, \mathrm{Cu}_{2} \mathrm{~S}$, and $\mathrm{Sb}_{2} \mathrm{~S}_{3}$ powders [30] or mixing with salt flux ( $\mathrm{KCl}$ and $\mathrm{LiCl})$ [12] in a sealed quartz tube. However, the susceptibility is different for polycrystalline $\mathrm{Cu}_{12} \mathrm{Sb}_{4} \mathrm{~S}_{13}$ (negative below $\left.\mathrm{T}_{\mathrm{MST}}\right)$ prepared from ingredients $(\mathrm{Cu}, \mathrm{Sb}, \mathrm{S}$ powders) [18]. The differences in positive and negative $\chi$ value for $\mathrm{Cu}_{12} \mathrm{Sb}_{4} \mathrm{~S}_{13}$ are connected with the small deviation in composition [18]. Moreover, the variation amplitude of $\chi$ value is smaller at around $\mathrm{T}_{\mathrm{MPT}}$.

Magnetic hysteresis is observed around $\mathrm{T}_{\mathrm{MPT}}$ in $\chi(\mathrm{T})$ curves as shown in the inset of Fig. 5, which suggests that the magnetic phase transition is the first-order phase transition. This result is consistent with the hysteresis observed in heat capacity reported by Suekuni et al [18]. However, in contrast to $\chi(\mathrm{T})$ for $\mathrm{Cu}_{12} \mathrm{Sb}_{4} \mathrm{~S}_{13}$ and $\mathrm{Cu}_{11.9} \mathrm{Sb}_{4} \mathrm{~S}_{13}, \chi(\mathrm{T})$ values were larger possibly due to the existence of $\mathrm{Cu}$ rich tetrahedrite $\mathrm{Cu}_{11.22} \mathrm{Sb}_{4} \mathrm{~S}_{13}$.

The reported $\chi$ value for $\mathrm{Cu}_{12} \mathrm{Sb}_{4} \mathrm{~S}_{13}$ at low temperature $(\mathrm{T}<25 \mathrm{~K})$, was a bit larger than the value for $\mathrm{Cu}_{12} \mathrm{Sb}_{4} \mathrm{~S}_{13}$ reported in the literature [12] $(0.0041 \mathrm{emu} / \mathrm{mol})$, [30] (less than $0.001 \mathrm{emu} / \mathrm{mol}$ ) and [18] at $2 \mathrm{~K}$ but was similar to $\chi$ values of natural tetrahedrite-tennantite (above $0.15 \mathrm{emu} / \mathrm{mol}$ ) [15]. It might be attributed to $\mathrm{Fe}$ impurities. At $\mathrm{T}>90 \mathrm{~K}$, a Curie-Weiss type behavior is observed. According to the Curie-Weiss law, $\chi=C /(T-\theta)$, the Curie constant $C$ and Weiss constant $\theta$ were fitted and listed in Table 2 . The $\theta$ of $\mathrm{Cu}_{11.9} \mathrm{Sb}_{4} \mathrm{~S}_{12.9}$ is similar to the reported

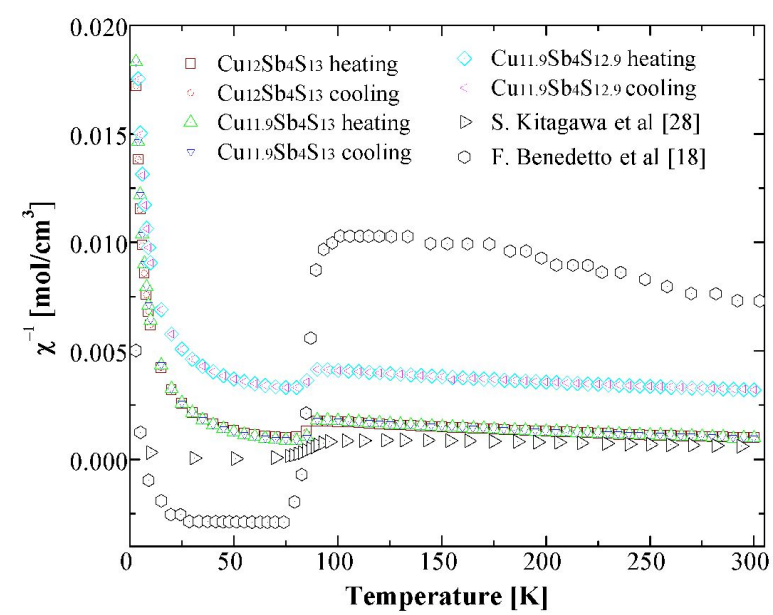

Fig. 5. Temperature dependencies of magnetic susceptibility $\chi$ in $2 \mathrm{~K}$ to $300 \mathrm{~K}$ range.

value of $-566.14 \mathrm{~K}$ [12]. For $\mathrm{Cu}_{12} \mathrm{Sb}_{4} \mathrm{~S}_{13}$ and $\mathrm{Cu}_{11.9} \mathrm{Sb}_{4} \mathrm{~S}_{13}$, both $\mathrm{C}$ and $\theta$ are smaller, which is related to the valence of Fe ion (Table 1). The influence of Fe content on $\chi$ and $\theta$ depends on the Fe valence (antiferromagnetic for $\mathrm{Fe}^{2+}$ ions) in the natural tetrahedrites $[15,31]$.

Magnetization $\mathrm{M}$ for $\mathrm{Cu}_{12} \mathrm{Sb}_{4} \mathrm{~S}_{13}$, $\mathrm{Cu}_{11.9} \mathrm{Sb}_{4} \mathrm{~S}_{13}$, and $\mathrm{Cu}_{11.9} \mathrm{Sb}_{4} \mathrm{~S}_{12.9}$ as a function of applied magnetic field $\mathrm{H}$ at $300 \mathrm{~K}$ is shown in Fig. 6. All $\mathrm{M}(\mathrm{H})$ show linear increase with increasing magnetic field. This behavior suggests that the crystal electric field (CEF) state at room temperature is nonmagnetic. The field dependence and non-saturation may be related to the polarization of conduction electrons which mix in the higher-lying CEF states with increasing field. The $\mathrm{M}$ reveals a weak paramagnetic behavior for $\mathrm{Cu}_{12} \mathrm{Sb}_{4} \mathrm{~S}_{13}$ and $\mathrm{Cu}_{11.9} \mathrm{Sb}_{4} \mathrm{~S}_{13}$. However, the magnetization for $\mathrm{Cu}_{11.9} \mathrm{Sb}_{4} \mathrm{~S}_{12.9}$ is nonlinear and similar to ferromagnetic behavior below $1 \mathrm{~T}$ due to the effect of impurity, which is different from the natural tetrahedrite with ferromagnetic behavior at $300 \mathrm{~K}$ [15].

Fig. 7 a shows the heat capacity $\mathrm{C}_{\mathrm{p}}$ for the synthetic $\mathrm{Cu}_{11.9} \mathrm{Sb}_{4} \mathrm{~S}_{13}$ and $\mathrm{Cu}_{12} \mathrm{Sb}_{4} \mathrm{~S}_{13}$ samples in the range of $2 \mathrm{~K}$ to $200 \mathrm{~K}$. The $\mathrm{C}_{\mathrm{p}}$ of $\mathrm{Cu}_{11.9} \mathrm{Sb}_{4} \mathrm{~S}_{13}$ decreases with decreasing temperature almost linearly in the range of $90 \mathrm{~K}$ to $200 \mathrm{~K}$. The $\mathrm{C}_{\mathrm{p}}$ for $\mathrm{Cu}_{12} \mathrm{Sb}_{4} \mathrm{~S}_{13}$ has a higher transition at around 
Table 2. Curie-Weiss constants for $\mathrm{Cu}_{12} \mathrm{Sb}_{4} \mathrm{~S}_{13}, \mathrm{Cu}_{11.9} \mathrm{Sb}_{4} \mathrm{~S}_{13}$, and $\mathrm{Cu}_{11.9} \mathrm{Sb}_{4} \mathrm{~S}_{12.9}$

\begin{tabular}{cccccccc}
\hline $\begin{array}{c}\text { Curie/Weiss } \\
\text { constant }\end{array}$ & \multicolumn{2}{c}{$\mathrm{Cu}_{12} \mathrm{Sb}_{4} \mathrm{~S}_{13}$} & \multicolumn{2}{c}{$\mathrm{Cu}_{11.9} \mathrm{Sb}_{4} \mathrm{~S}_{13}$} & \multicolumn{2}{c}{$\mathrm{Cu}_{11.9} \mathrm{Sb}_{4} \mathrm{~S}_{12.9}$} & $\mathrm{Cu}_{12} \mathrm{Sb}_{4} \mathrm{~S}_{13}$ [12] \\
\hline \hline $\mathrm{C}\left[\mathrm{emu} \cdot \mathrm{K} \cdot \mathrm{mol}^{-1}\right]$ & 0.46 & 0.46 & 0.44 & 0.43 & 2.66 & 2.77 & 1.523 \\
$\theta[\mathrm{K}]$ & -159.19 & -156.93 & -145.08 & -136.16 & -574.34 & -574.24 & -566.14 \\
\hline
\end{tabular}

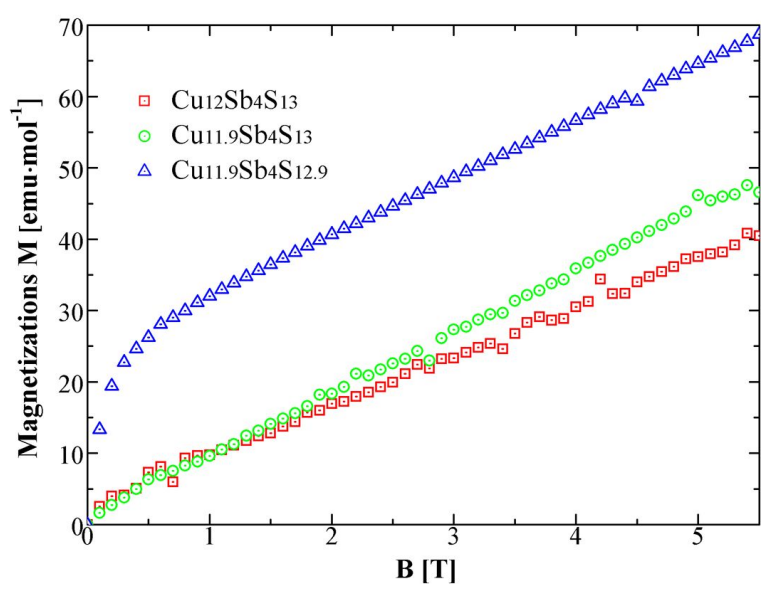

Fig. 6. Magnetization $\mathrm{M}$ as a function of applied magnetic field at $300 \mathrm{~K}$.

$150 \mathrm{~K}$, possibly due to the second phase. After the sharp peak occurring at $88.1 \mathrm{~K}$ and ending at $80 \mathrm{~K}$, the linear behavior is followed. Moreover, the corresponding temperature for the maximum value is different for $\mathrm{Cu}_{12} \mathrm{Sb}_{4} \mathrm{~S}_{13}(85.3 \mathrm{~K})$ and $\mathrm{Cu}_{11.9} \mathrm{Sb}_{4} \mathrm{~S}_{13}(84.8 \mathrm{~K})$ as shown the inset of Fig. $7 \mathrm{a}$. The difference in the transition temperatures is associated with the latent heat during phase transformation [5]. Below $30 \mathrm{~K}, \mathrm{C}_{\mathrm{p}}$ for both samples is almost the same as that reported for $\mathrm{Cu}_{12} \mathrm{Sb}_{4} \mathrm{~S}_{13}$ [32], which suggests that the impurity elements in stibnite have little effect on the heat capacity. The $\mathrm{C}_{\mathrm{p}} / \mathrm{T}^{3}$ versus $\mathrm{T}^{2}$ dependence is shown in Fig. $7 \mathrm{~b}$. The $\mathrm{C}_{\mathrm{p}} / \mathrm{T}^{3}$ vs. $\mathrm{T}^{2}$ plot reveals a broad asymmetric maximum centered at $7200 \mathrm{~K}^{2}$.

\subsection{Electrical and thermal transport properties of synthetic $\mathrm{Cu}_{12} \mathrm{Sb}_{4} \mathbf{S}_{13}$}

Fig. 8 shows temperature dependencies of electrical resistivity $\rho(\mathrm{T})(\mathrm{a})$, Seebeck coefficient $S(\mathrm{~b})$, thermal conductivity $K(\mathrm{c})$ and thermoelectric figure of merit (d) for $\mathrm{Cu}_{11.9} \mathrm{Sb}_{4} \mathrm{~S}_{13}$ and $\mathrm{Cu}_{12} \mathrm{Sb}_{4} \mathrm{~S}_{13}$. Below $90 \mathrm{~K}$, the $\rho(\mathrm{T})$ of $\mathrm{Cu}_{11.9} \mathrm{Sb}_{4} \mathrm{~S}_{13}$ decreases
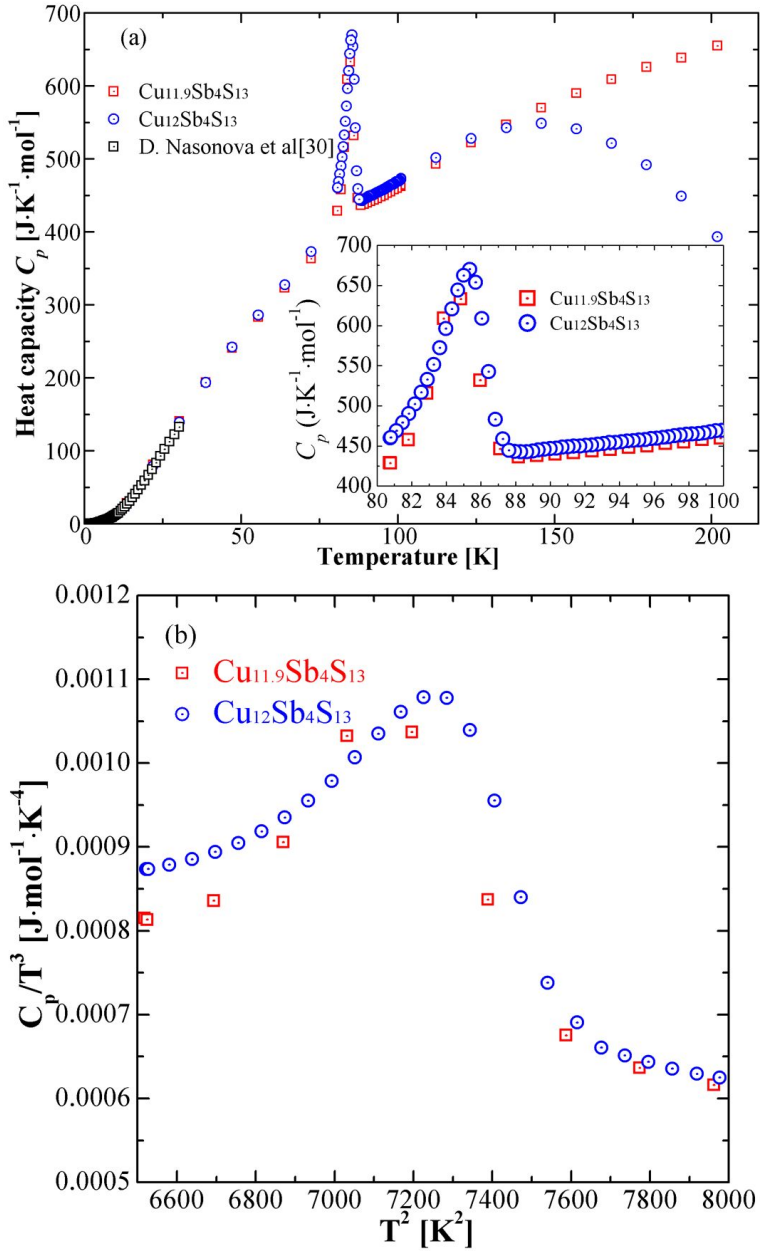

Fig. 7. (a) Heat capacity of the synthetics in the range of $2 \mathrm{~K}$ to $200 \mathrm{~K}$ and (b) $\mathrm{C}_{\mathrm{p}} / \mathrm{T}^{3}$ versus $\mathrm{T}^{2}$ dependence.

exponentially as temperature increases from $2 \mathrm{~K}$ to $90 \mathrm{~K}$, indicating a semiconductor-like behavior. However, the $\rho(\mathrm{T})$ decreases slightly from $0.02 \Omega$. $\mathrm{mm}$ to $0.01 \Omega \cdot \mathrm{mm}$ as temperature increases from $90 \mathrm{~K}$ to $400 \mathrm{~K}$. This behavior indicates that there is a phase transition in $\mathrm{Cu}_{11.9} \mathrm{Sb}_{4} \mathrm{~S}_{13}$ at about $90 \mathrm{~K}$. The $\rho(\mathrm{T})$ of $\mathrm{Cu}_{12} \mathrm{Sb}_{4} \mathrm{~S}_{13}$ also exhibits similar transition behavior at about $90 \mathrm{~K}$. Meanwhile, the $\rho(\mathrm{T})$ 

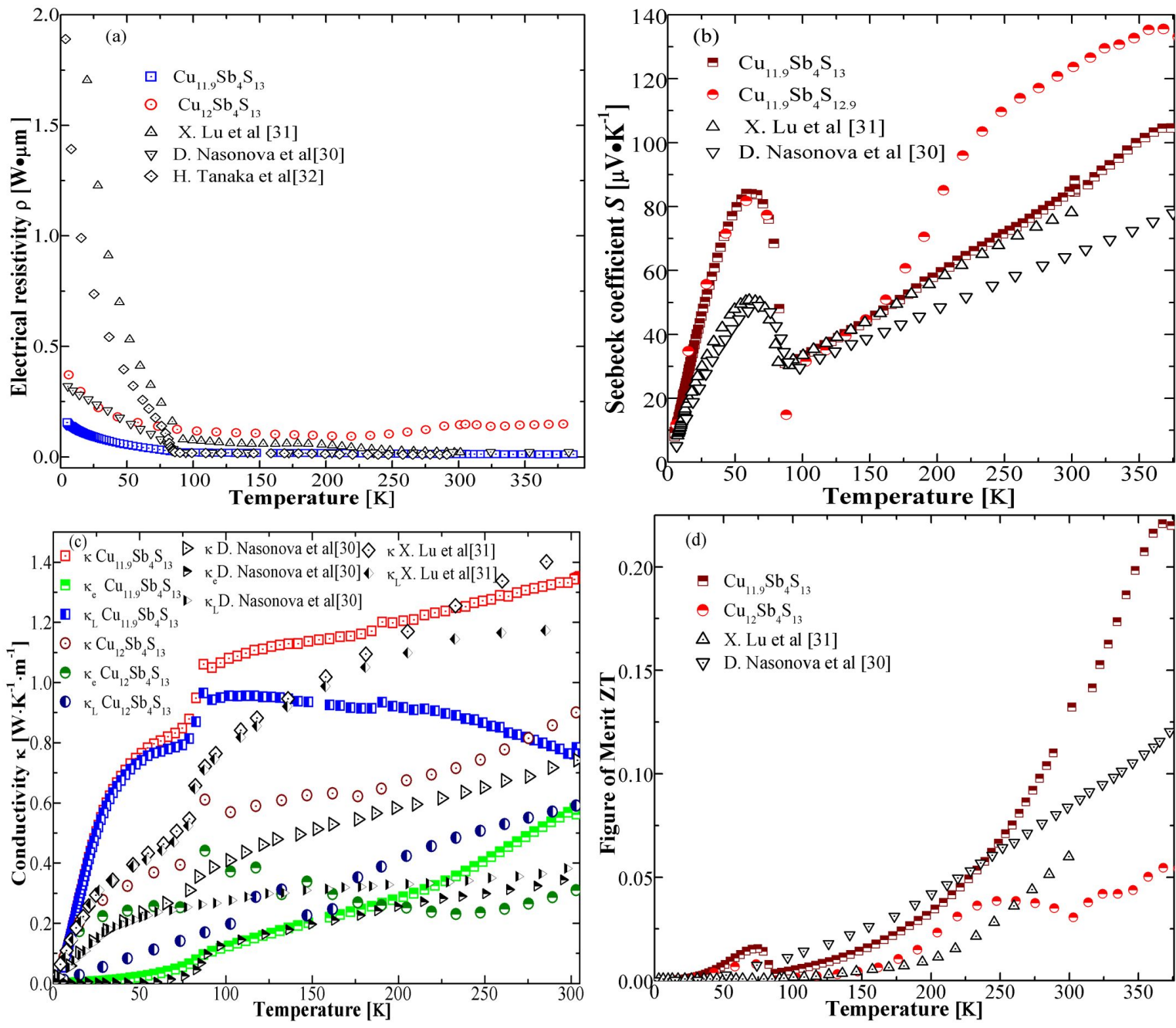

Fig. 8. Temperature dependencies of the electrical resistivity (a), Seebeck coefficient (b), thermal conductivity (c) and the thermoelectric figure of merit (d) for $\mathrm{Cu}_{11.9} \mathrm{Sb}_{4} \mathrm{~S}_{13}$ and $\mathrm{Cu}_{12} \mathrm{Sb}_{4} \mathrm{~S}_{13}$.

of $\mathrm{Cu}_{12} \mathrm{Sb}_{4} \mathrm{~S}_{13}$ exhibits an extra transition from semimetal to semiconductor at about $230 \mathrm{~K}$. Considering the fact that isostructural $\mathrm{Cu}_{11.9} \mathrm{Sb}_{4} \mathrm{~S}_{13}$ does not show any transition around $230 \mathrm{~K}$, the reason for the MI transition of $\mathrm{Cu}_{12} \mathrm{Sb}_{4} \mathrm{~S}_{13}$ should not be caused by the crystallographic transformation, nor magnetic phase transition, but it might be a special sublattice (such as point defect) due to the lack of $\mathrm{Cu}$ and $\mathrm{S}$ atom in the unit crystal lattice. The present samples show lower $\rho(\mathrm{T})$ than that reported by Lu et al. [33] and Nasonova et al. [32], and are close to the values reported by Tanaka et al. [34]. The reduced $\rho(\mathrm{T})$ results from the increased number of grain boundaries formed during the repeated sintering [14].
The $\mathrm{S}$ for both $\mathrm{Cu}_{11.9} \mathrm{Sb}_{4} \mathrm{~S}_{13}$ and $\mathrm{Cu}_{12} \mathrm{Sb}_{4} \mathrm{~S}_{13}$ are positive in the whole temperature range, proving that holes are the major carriers. Above $90 \mathrm{~K}$, the $\mathrm{S}$ increases almost linearly with temperature, suggesting that ionized impurity scattering is the most probable mechanism for both $\mathrm{Cu}_{11.9} \mathrm{Sb}_{4} \mathrm{~S}_{13}$ and $\mathrm{Cu}_{12} \mathrm{Sb}_{4} \mathrm{~S}_{13}$. The $\mathrm{S}$ for $\mathrm{Cu}_{12} \mathrm{Sb}_{4} \mathrm{~S}_{13}$ is larger than that of $\mathrm{Cu}_{11.9} \mathrm{Sb}_{4} \mathrm{~S}_{13}$ due to the difference in composition. The $\mathrm{S}$ for $\mathrm{Cu}_{11.9} \mathrm{Sb}_{4} \mathrm{~S}_{13}$ is similar to that reported by $\mathrm{Lu}$ et al. [33] but larger than that reported by Nasonova et al. [32].

Below $90 \mathrm{~K}$, the $\mathrm{S}$ increases up to the maximal value $\left(84 \mu \mathrm{V} \cdot \mathrm{K}^{-1}\right.$ for $\mathrm{Cu}_{11.9} \mathrm{Sb}_{4} \mathrm{~S}_{13}$ and $82 \mu \mathrm{V} \cdot \mathrm{K}^{-1}$ for $\mathrm{Cu}_{12} \mathrm{Sb}_{4} \mathrm{~S}_{13}$ at $59 \mathrm{~K}$ ) and then decreases with decreasing temperature. 
The anomalous change in $\mathrm{S}$ may be related to the magnetic phase transition at around $90 \mathrm{~K}$, which is consistent with magnetic data (Fig. 6) and specific heat (Fig. 8a). The origin of the maximum might arise from an exchange polarization or jumping of conduction electrons.

The thermal conductivities $\kappa$ for both $\mathrm{Cu}_{11.9} \mathrm{Sb}_{4} \mathrm{~S}_{13}$ and $\mathrm{Cu}_{12} \mathrm{Sb}_{4} \mathrm{~S}_{13}$ increase with the rise of temperature. A sharp increase at $90 \mathrm{~K}$ is observed for both $\mathrm{Cu}_{11.9} \mathrm{Sb}_{4} \mathrm{~S}_{13}$ and $\mathrm{Cu}_{12} \mathrm{Sb}_{4} \mathrm{~S}_{13}$. The total thermal conductivity $\kappa$ for $\mathrm{Cu}_{12} \mathrm{Sb}_{4} \mathrm{~S}_{13}$ is smaller than that of $\mathrm{Cu}_{11.9} \mathrm{Sb}_{4} \mathrm{~S}_{13}$. Similar to that reported by $\mathrm{Lu}$ et al. [33], the $\kappa_{\mathrm{L}}$ for $\mathrm{Cu}_{11.9} \mathrm{Sb}_{4} \mathrm{~S}_{13}$ is far greater than that of $\kappa_{\mathrm{e}}$. However, the differences in $\kappa_{\mathrm{L}}$ and $\kappa_{\mathrm{e}}$ for $\mathrm{Cu}_{12} \mathrm{Sb}_{4} \mathrm{~S}_{13}$ are relatively small in comparison to those reported by Nasonova et al. [32].

The maximum values of figure of merit $\mathrm{ZT}$ for $\mathrm{Cu}_{11.9} \mathrm{Sb}_{4} \mathrm{~S}_{13}$ and $\mathrm{Cu}_{12} \mathrm{Sb}_{4} \mathrm{~S}_{13}$ are 0.2 and 0.05 at $367 \mathrm{~K}$, respectively. Compared with the ZT values reported by $\mathrm{Lu}$ et al. [33] and Nasonova et al. [32], the impurity elements in stibnite ore have a weak influence on the low-temperature thermoelectric properties.

\section{Conclusions}

High purity $\mathrm{Cu}_{12} \mathrm{Sb}_{4} \mathrm{~S}_{13}$ has been synthesized from stibnite $\mathrm{Sb}_{2} \mathrm{~S}_{3}$ by SPS in the temperatures from the range of $420{ }^{\circ} \mathrm{C}$ to $440{ }^{\circ} \mathrm{C}$. The reduction of $\mathrm{Cu} / \mathrm{CuS}$ content and resintering can reduce the impurities in $\mathrm{Cu}_{3} \mathrm{SbS}_{4}$ and $\mathrm{CuS}$. A magnetic phase transition was observed for all measured magnetizations and heat capacities. Both the susceptibility and magnetization revealed the paramagnetic behavior of this compound. The $\mathrm{C}_{\mathrm{p}}$ showed a sharp peak between $80 \mathrm{~K}$ and $88 \mathrm{~K}$. The transformation behavior at $90 \mathrm{~K}$ was also observed in case of resistivity, Seebeck coefficient and thermal conductivity. The optimized $\mathrm{ZT}$ value was 0.22 at $368 \mathrm{~K}$ for $\mathrm{Cu}_{12} \mathrm{Sb}_{4} \mathrm{~S}_{13}$. Based on the low temperature physical properties, stibnite ore impurities have little effect on $\mathrm{Cu}_{12} \mathrm{Sb}_{4} \mathrm{~S}_{13}$, so the utilization of stibnite ore $\mathrm{Sb}_{2} \mathrm{~S}_{3}$ as raw material for the preparation of tetrahedrite $\mathrm{Cu}_{12} \mathrm{Sb}_{4} \mathrm{~S}_{13}$ is possible. The effect of stibnite minerals on high temperature thermoelectric properties of $\mathrm{Cu}_{12} \mathrm{Sb}_{4} \mathrm{~S}_{13}$ will be the subject of further studies.

\section{Acknowledgements}

The present work was partially supported by the Scientific Research (B) No. 16H04542 and 24360314 from the Ministry of Education, Science, Sports and Culture of Japan. Financial supports from the Natural Science Foundation of China under Grant No. 51802189. And the Doctoral Scientific Research Foundation of Shanghai Dianji University (A1-028819-029-01), the Research Foundation for Advanced Talents of Nanyang Normal University (2019ZX018).

\section{References}

[1] Yang M., Su T., Zhu H., Li S., Hu M., Hu Q., MA H., JiA X., J. Mater. Sci., 53 (2018), 11524.

[2] Zhu H., Su T., Li H., Pu C., Zhou D., Zhu P., WANG X., J. Eur. Ceram. Soc., 37 (2017), 1541.

[3] WAng J., GU M., BAO Y., Li X., ChEN L., J. Electron. Mater., 45 (2016), 2274.

[4] Lu X., Morelli D.T., Phys. Chem. Chem. Phys., 15 (2013), 5762.

[5] May A.F., Delaire O., Niedziela J.L., LaraCurzio E., Susner M.A., ABernathy D.L., Kirkham M., MCGuire M.A., Phys. Rev. B, 93 (2016), 064104.

[6] Lu X., Morelli D.T., Xia Y., Zhou F., Ozolins V., Chi H., ZHou X., Uher C., Adv. Energy Mater., 3 (2013), 342.

[7] Suekuni K., Tsuruta K., Ariga T., Koyano M., Appl. Phys. Express, 5 (2012), 051201.

[8] Suekuni K., Tsuruta K., Kunit M., Nishiate H., Nishibori E., MaKi S., OHTA M., YAMAMOto A., Koyano M., J. Appl. Phys., 113 (2013), 043712.

[9] LU X., Morelli D., J. Electron. Mater., 43 (2014), 1983.

[10] Heo J., Laurita G., Muir S., Subramanian M.A., Keszler D.A., Chem. Mater., 26 (2014), 2047.

[11] Laracurzio E., May A.F., Delaire O., McGuire M.A., Lu X., LiU C.Y., CASE E.D., Morelli D.T., J. Appl. Phys., 115 (2014), 193515.

[12] Di Benedetto F., Bernardini G., Cipriani C., Emiliani C., Gatteschi D., Romanelli M., Phys. Chem. Miner, 32 (2005), 155.

[13] Bouyrie Y., Candolfi C., Ohorodnitchuk V., Malaman B., Dauscher A., Tobola J., Lenoir B., J. Mater. Chem. C, 3 (2015), 10476.

[14] Sun F.H., Wu C.F., Li Z., PAN Y., AsfandiYar, DONG J., Li J.F., RSC Adv., 7 (2017), 18909.

[15] LeVinsky P., VAney J.-B., CAndolfi C., DAUSChER A., LENOIR B., HeJTMÁNEK J., $J$. Electron. Mater., 45 (2016), 1351.

[16] Lu X., Morelli D.T., MRS Commun., 3 (2013), 129.

[17] Tippireddy S., Chetty R., Naik M.H., Jain M., Chattopadhyay K., Mallik R.C., J. Phys. Chem. C, 122 (2018), 8735. 
[18] Suekuni K., Tomizawa Y., Ozaki T., Koyano M., J. Appl. Phys., 115 (2014), 143702.

[19] Weller D.P., Kunkel G.E., OChs A.M., Morelli D.T., Anderson M.E., Mater. Today Phys., 7 (2018), 1.

[20] Sobolev A.V., Presniakov I.A., Nasonova D.I., Verchenko V.Y., Shevelkov A.V., J. Phys. Chem. $C, 121$ (2017), 4548.

[21] Bouyrie Y., Sassi S., Candolfi C., Vaney J.-B., Dauscher A., LenoIr B., Dalton T., 45 (2016), 7294.

[22] Sun F.H., Dong J., DeY S., Wu C.F., PAN Y., TANG H., Li J.F., Sci. China Mater., 9 (2018), 1209.

[23] Nasonova D.I., Sobolev A.V., Presniakov I.A., Andreeva K.D., Shevelkov A.V., J. Alloy. Compd., 778 (2019), 774.

[24] Huang L.L., Wang Y.S., Zhu C., Xu R., Li J.M., Zhang J.H., Li D., WANG Z.M., WANG L., SONG C.J., XIN H.X., Zhang J., QIN X.Y., J. Alloy. Compd., 769 (2018), 478.

[25] Kumar D.P., Chetty R., Femi O., ChattopadHYAY K., MALAR P., MALliK R., J. Electron. Mater. 46 (2017), 2616.

[26] Suekuni K., Lee C.H., Tanaka H.I., Nishibori E., Nakamura A., Kasai H., Mori H., Usui H., Ochi M., Hasegawa T., Adv. Mater., (2018), 1706230.

[27] Lu X., Morelli D.T., Xia Y., Ozolins V., Chem. Mater., 27 (2015), 408.
[28] Skinner B.J., Luce F.D., Makovicky E., Econ Geol. 67 (1972), 924.

[29] Welch A.W., ZaWadzki P.P., Lany S., Wolden C.A., Zakutayev A., Sol. Energy Mat. Sol. C., 132 (2015), 499.

[30] Kitagawa S., Sekiya T., Araki S., Kobayashi T.C., IShida K., Kambe T., KimURA T., Nishimoto N., Kudo K., Nohara M., J. Phys. Soc. Jpn., 84 (2015), 093701.

[31] Benedetto Di F., Bernardini G.P., Borrini D., Emiliani C., Cipriani C., Danti C., Caneschi A., Gatteschi D., Romanelli M., Can. Mineral., 40 (2002), 837.

[32] Nasonova D.I., Verchenko V.Y., Tsirlin A.A., Shevelkov A.V., Chem. Mater, 28 (2016), 6621.

[33] Lu X., YAO W., Wang G., Zhou X., Morelli D., Zhang Y., Chi H., Hui S., Uher C., J. Mater. Chem. A, 4 (2016), 17096.

[34] Tanaka H.I., Suekuni K., Umeo K., Nagasaki T., Sato H., Kutluk G., Nishibori E., Kasai H., Takabatake T., J. Phys. Soc. Jpn., 85 (2015), 014703.

Received 2018-12-17 Accepted 2019-04-23 